\title{
UNINTENDED NEGATIVE EFFECTS OF CLIENT PROJECT COST CONTROLS: A SYSTEM DYNAMICS APPROACH
}

\author{
A.M. Chitongo ${ }^{1 * \#} \&$ L. Pretorius ${ }^{1}$
}

\section{ARTICLE INFO}

\section{Article details}

Presented at the $29^{\text {th }}$ annual conference of the Southern African Institute for Industrial Engineering (SAIIE), held from 24-26 October 2018 in Stellenbosch, South Africa

Available online $\quad 9$ Nov 2018

\section{Contact details}

Corresponding author u12279422@tuks.co.za

\section{Author affiliations}

1 Department of Engineering and Technology Management, University of Pretoria, South Africa

\# The author was enrolled for a PhD (Project Management) degree in the Department of Engineering and Technology Management, University of Pretoria, South Africa.

DOI

http://dx.doi.org/10.7166/29-3-2054

\section{ABSTRACT}

Project controls have been defined in the existing literature as managerial decisions and actions aimed at rectifying poor project performance. Understanding the potential unintended negative effects of such controls will be beneficial to project management practice and to the resulting project performance. Using the system dynamics approach, this article investigates some unintended negative effects of client project cost controls. Empirical data from a raw-water infrastructure project are used to calibrate the formulated system dynamics simulation model. Simulation results suggest that the client project cost controls (aimed at minimising project cost), unintentionally generate some counteractive effects (an increase in the project cost and the time schedule duration).

\section{OPSOMMING}

Projekkontroles is in die literatuur gedefinieer as bestuursbesluite en aksies wat daarop gemik is om swak projekprestasie reg te stel. Om die potensiële onbedoelde negatiewe gevolge van sulke kontroles te begryp, sal voordelig wees vir projekbestuurspraktyke en die gevolglike projekprestasie. Met behulp van 'n stelseldinamika-benadering, ondersoek hierdie artikel 'n paar onbedoelde negatiewe gevolge van kliëntprojekkostekontroles. Empiriese data uit 'n rou-water-infrastruktuurprojek word gebruik om die geformuleerde stelseldinamika simulasiemodel te kalibreer. Simulasie resultate dui daarop dat die kliënt projek koste kontrole (gemik op die vermindering van projek koste), onbedoeld sommige teenproduktiewe effekte genereer ('n toename in die projek koste en die projek tydsduur).

\section{INTRODUCTION}

Infrastructure development plays a pivotal supporting role in the economic development of any country, as highlighted by many scholars, including Ansar, Flyvbjerg, Budzier and Lunn [1] and Vickerman [2]. There are different types of infrastructure, as is evident from many previous projects-related research studies. They include, among others, those related to: airports [3]; educational and health facilities [4] [5]; electricity [6] [7]; rail [2]; roads [8]; and water [9]. While some infrastructure projects are success stories, there are many cases of poor project performance (especially time schedule delays and cost budget over-runs), as highlighted by Ansar et al. [1], Morris [10], Kaliba et al. [8], and Standish [11].

Project managers (the client, engineering consultant, and construction contractor) take a number of project controls aimed at minimising poor project performance. However, some of their efforts tend to be in vain, as their decisions and actions quite often generate some unintended and counteractive effects that worsen the project performance [12] [13] [14] [15]. This is as a result of the dynamic complexity nature of project controls [14] [16] [17]; hence the use of system dynamics in this article, consistent with the recommendations of Sterman [17] and Forrester [18]. 
In particular, the objectives of this article are: to investigate, from the existing literature and empirically, some of the client project cost controls and their unintended effects; to formulate an appropriate system dynamics conceptual model; to formulate an appropriate initial system dynamics simulation model; to calibrate the system dynamics simulation model using real-world project data; and to conduct a Monte Carlo sensitivity analysis on some of the key assumptions (model parameters).

The rest of this article is structured as follows: a review of some of the relevant existing literature; an outline of the research methodology followed; a presentation and discussion of the formulated system dynamics conceptual model; a presentation and discussion of key simulation results (calibration and sensitivity analysis) of the initial system dynamics simulation model; and conclusions and recommendations for further research.

\section{LITERATURE REVIEW}

\subsection{Client contributions to poor project performance}

Table 1 shows some of the ways in which the client negatively (often unintentionally) affects project performance, as found in the reviewed extant literature.

Table 1: Some client contributions to poor project performance

\begin{tabular}{|c|c|c|}
\hline Client action & $\begin{array}{l}\text { Project performance } \\
\text { measure negatively } \\
\text { affected }\end{array}$ & Example references \\
\hline Project scope changes & $\begin{array}{l}\text { time schedule; } \\
\text { cost }\end{array}$ & $\begin{array}{l}\text { De Marco [7]; Fallahnejad [19]; Ford et al. } \\
\text { [15]; Kaliba et al. [8]; Rodrigues and Williams } \\
\text { [20]; Sterman [16] }\end{array}$ \\
\hline $\begin{array}{l}\text { Delay in paying engineering } \\
\text { consultants and/or construction } \\
\text { contractors }\end{array}$ & time schedule & $\begin{array}{l}\text { Chitongo and Pretorius [12]; Fallahnejad [19]; } \\
\text { Kaliba et al. [8]; Manu, Ankrah, Chinyio and } \\
\text { Proverbs [21]; Odeh and Battaineh [22]; } \\
\text { Sambasivan and Soon [23] }\end{array}$ \\
\hline $\begin{array}{l}\text { Instituting delay damages } \\
\text { penalty }\end{array}$ & time schedule & $\begin{array}{l}\text { Von Branconi and Loch [24]; Chitongo and } \\
\text { Pretorius [12] }\end{array}$ \\
\hline $\begin{array}{l}\text { Demanding more progress } \\
\text { reports from the engineering } \\
\text { consultant and/or construction } \\
\text { contractor }\end{array}$ & time schedule & $\begin{array}{l}\text { Rodrigues and Williams [20]; Chitongo and } \\
\text { Pretorius [12] }\end{array}$ \\
\hline $\begin{array}{l}\text { Demanding more progress } \\
\text { meetings from the engineering } \\
\text { consultant }\end{array}$ & time schedule & Chitongo and Pretorius [12] \\
\hline $\begin{array}{l}\text { Delay in reviewing and/or } \\
\text { approving deliverables }\end{array}$ & time schedule & Rodrigues and Williams [20] \\
\hline Slow decision-making & time schedule & Odeh and Battaineh [22] \\
\hline $\begin{array}{l}\text { Appointing incompetent } \\
\text { engineering consultants / } \\
\text { construction contractors }\end{array}$ & $\begin{array}{l}\text { time schedule; } \\
\text { quality of deliverables }\end{array}$ & $\begin{array}{l}\text { Fallahnejad [19]; Odeh and Battaineh [22]; } \\
\text { Sambasivan and Soon [23] }\end{array}$ \\
\hline $\begin{array}{l}\text { Nominating incompetent sub- } \\
\text { consultants / sub-contractors }\end{array}$ & & \\
\hline
\end{tabular}

This study investigates some of the unintended negative effects of client project cost controls. 


\subsection{System dynamics modelling of project controls}

The term 'project controls' refers to well-intentioned managerial decisions and actions aimed at correcting poor project performance [14]. Understanding the potential unintended negative effects of such controls will be beneficial to project management practice and the resulting project performance.

The existing literature is replete with many cases of system dynamics modelling of project controls by different project stakeholders in a bid to try to enhance project performance, among other things, including: (presumed) engineering consultant / construction contractor project time schedule controls [14] [15]; construction contractor labour productivity control [25]; impacts of client behaviour on project time schedule performance [20]; engineering consultant project cash flow controls [13]; and engineering consultant project revenue controls [26]. More recently, Chitongo and Pretorius [12] examined the different measures of project performance as used and/or proposed by many previous scholars and researchers. They then narrowed their study to focus on investigating and formulating a system dynamics conceptual model of client project time schedule controls, with project time schedule duration being one the key measures of project performance.

This article focuses on investigating the unintended effects of client project cost controls, and their system dynamics modelling, as they are only sparingly covered in the literature reviewed.

The next section highlights the research methodology followed in this study.

\section{RESEARCH METHODOLOGY}

This research study employs a two-stage research design [27]. The first stage is an embedded multiple-case study [27] [28] that results in the formulation of a system dynamics conceptual model of client project cost controls and associated unintended effects. Non-project-specific qualitative data were gathered from a purposefully-selected major South African engineering consulting firm that focuses on infrastructure projects, as was the case in the study of Chitongo and Pretorius [12]. The non-project-specific data were gathered from multiple sources of evidence (triangulation) to enhance the construct validity of the case study [28]. The sources were: individual face-to-face semi-structured interviews with both client and engineering consultant project managers; nonparticipant casual observations during the interviews; and document analysis, also similar to that of Chitongo and Pretorius [12].

The gathered qualitative empirical data in this research study were analysed using a three-stage ('data condensation', 'data display', and 'conclusion drawing and verification') iterative, qualitative data analysis process recommended by Miles, Huberman and Saldana [29], similar to that used in the studies of Chitongo and Pretorius [12] and Manu et al. [21]. ATLAS.ti, a computer-assisted qualitative data analysis software [30], was used in this research study to aid the qualitative data analysis. Some of the key outputs of the Atlas.ti qualitative data analysis were causal networks of the client project cost controls and associated unintended effects that formed the basis of the formulation of the system dynamics causal loop diagrams (produced using Vensim software) shown in the next section.

Thus the system dynamics conceptual model of client project cost controls and associated unintended effects was formulated from a combination of the existing literature, key findings from an empirical embedded multiple-case study that captured the relevant formal and mental models of the interviewed contemporary client and engineering consultant project managers, and system dynamics' systems thinking tool (causal loop diagram). All of this was in line with the recommendations of Barlas [31], Luna-Reyes and Andersen [32], Martinez-Moyano and Richardson [33], and Sterman [17]. Previous research studies that followed a similar process include those of Chitongo and Pretorius [12], Manu et al. [21], and Mikulskiene and Pitrenaite-Zileniene [34].

In the second stage of this research study, the system dynamics conceptual model formulated in the previous stage was converted to an initial system dynamics simulation model using Vensim DSS software, by: developing an appropriate model structure (stocks and flows, and feedback loops); specifying mathematical equations for the relationships among the different model variables and 
parameters (constants), whilst ensuring dimensional consistency in all equations; specifying initial conditions, where applicable; and testing for extreme conditions, as recommended by MartinezMoyano and Richardson [33] and Sterman [17]. The formal description of the full system dynamics simulation model at stock and flow diagram level will be included as part of a future research publication by the authors of this article.

Real-world project-specific data (gathered through individual face-to-face semi-structured interviews with both client and engineering consultant project managers, and from document analysis) were then used to calibrate the formulated system dynamics simulation model [5] [35] of the client project cost controls and their unintended effects. Subsequently, the model was simulated, first without any client project cost controls, then with individual client project cost controls (first without and then with the associated unintended effects), and then with a combination of the client project cost controls (also, first without and then with the associated unintended effects). The impacts of the client project cost controls on project performance (as measured by project time duration and project cost, similar to Ford et al. [15], Parvan et al. [5], and De Marco [7]) were analysed and discussed. Subsequently, multivariate Monte Carlo sensitivity analysis was conducted to test the robustness of the calibration results [5].

The real-world project used in this study is related to raw-water infrastructure, and makes use of a time-based contract, with a ceiling price [36], between the client and the engineering consultant.

The next section presents key results from the first stage of the research study, the embedded multiple-case study.

\section{SYSTEM DYNAMICS CONCEPTUAL MODEL}

\subsection{Client project cost controls}

The control actions often taken by the client to try to bring a project that is forecast to be above cost budget back within budget, as found in this study, are similar to four of the client project time schedule controls in the study of Chitongo and Pretorius [12]. This seems logical, considering that both studies focus on time-based contracts. The four client project cost controls are: demanding more project progress reports; conducting more project progress meetings; conducting more project progress inspections; and delaying approval and payment of the engineering consultant's invoices.

In his discussion of the earned value method, Anbari [37] highlights that project cost variance is the difference between the earned value (budgeted cost of work performed) and the actual project cost of work performed; and that the project cost variance percentage is the project cost variance divided by the earned value, expressed as a percentage. He adds that the earned value is determined at any given time during project execution by multiplying the completed project proportion by the total project budget [37]. This means that the earned value at project completion equals the project budget at completion (or the contract ceiling price). Integrating this existing literature into the abovementioned client project cost controls and the study of Chitongo and Pretorius [12] yields a negative feedback loop, shown as a system dynamics causal loop diagram in Figure 1.

\subsection{Unintended effects of client project cost controls}

Three unintended effects ('less time spent on real work', 'haste makes waste', and 'insufficient project operating cash flow for the engineering consultant') of the client project cost controls are also similar to the unintended effects of the client project time schedule controls in the study of Chitongo and Pretorius [12]. A fourth unintended effect of all the client project cost controls, emerging from the current research study, is engineering consultant project revenue control in the form of effort adjustment [26]. Essentially, in the case of a time-based contract, the project cost incurred by the client equals the revenue realised by the engineering consultant from the same project. 


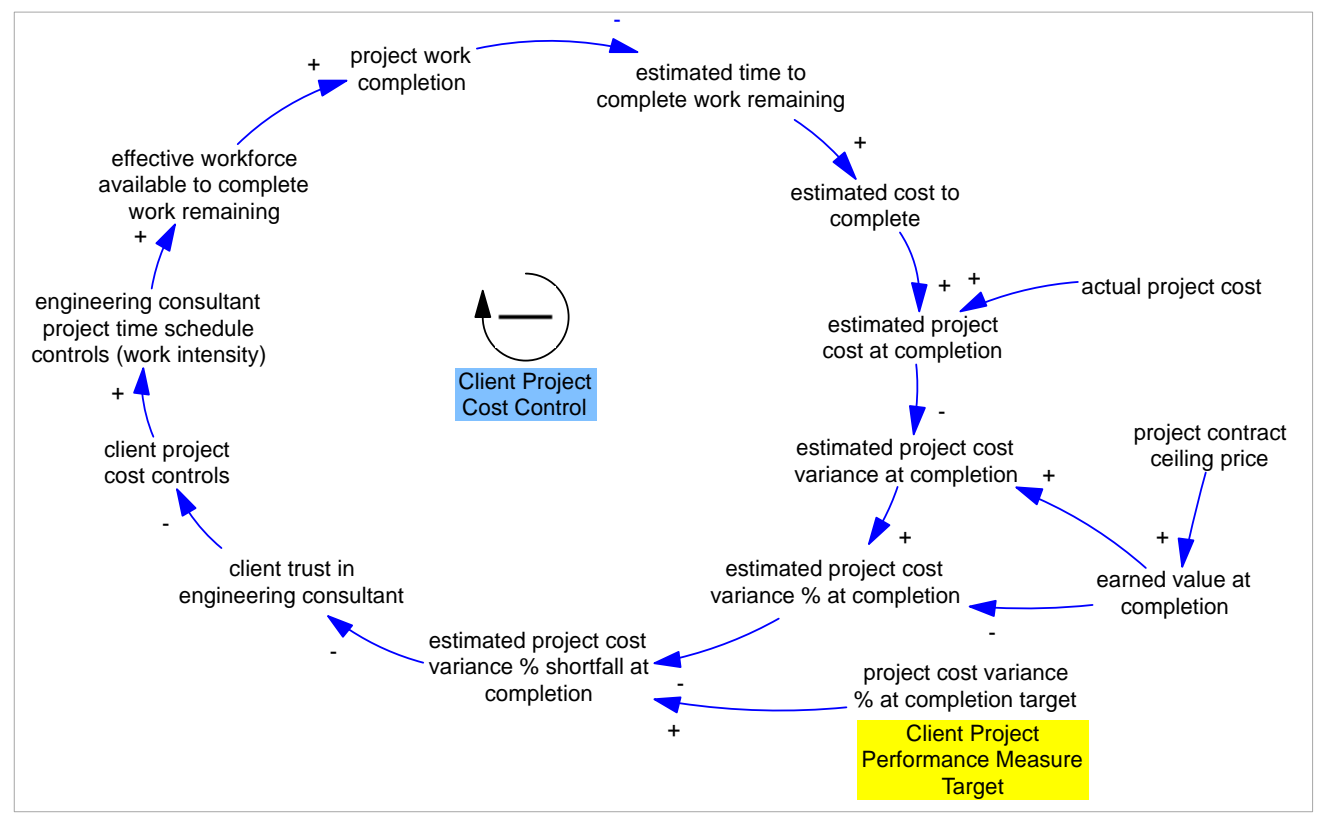

Figure 1: Client project cost controlling feedback (Source: Adapted from this study, Anbari [37], and Chitongo and Pretorius [12])

\subsection{Overall system dynamics conceptual model}

Combining the client project cost controls (negative feedback loops) and associated unintended effects (positive feedback loops) discussed in the preceding sub-sections yields the overall system dynamics conceptual model shown in Figure 2. The overall dynamic hypothesis shown in Figure 2 is that the client project cost controls (aimed at minimising project cost by increasing pressure/work intensity on the engineering consultant to complete project work faster) generate some counteractive and unintended negative effects (a decrease in project work completion rate, and an increase in the project cost) in the particular case of a time-based contract.

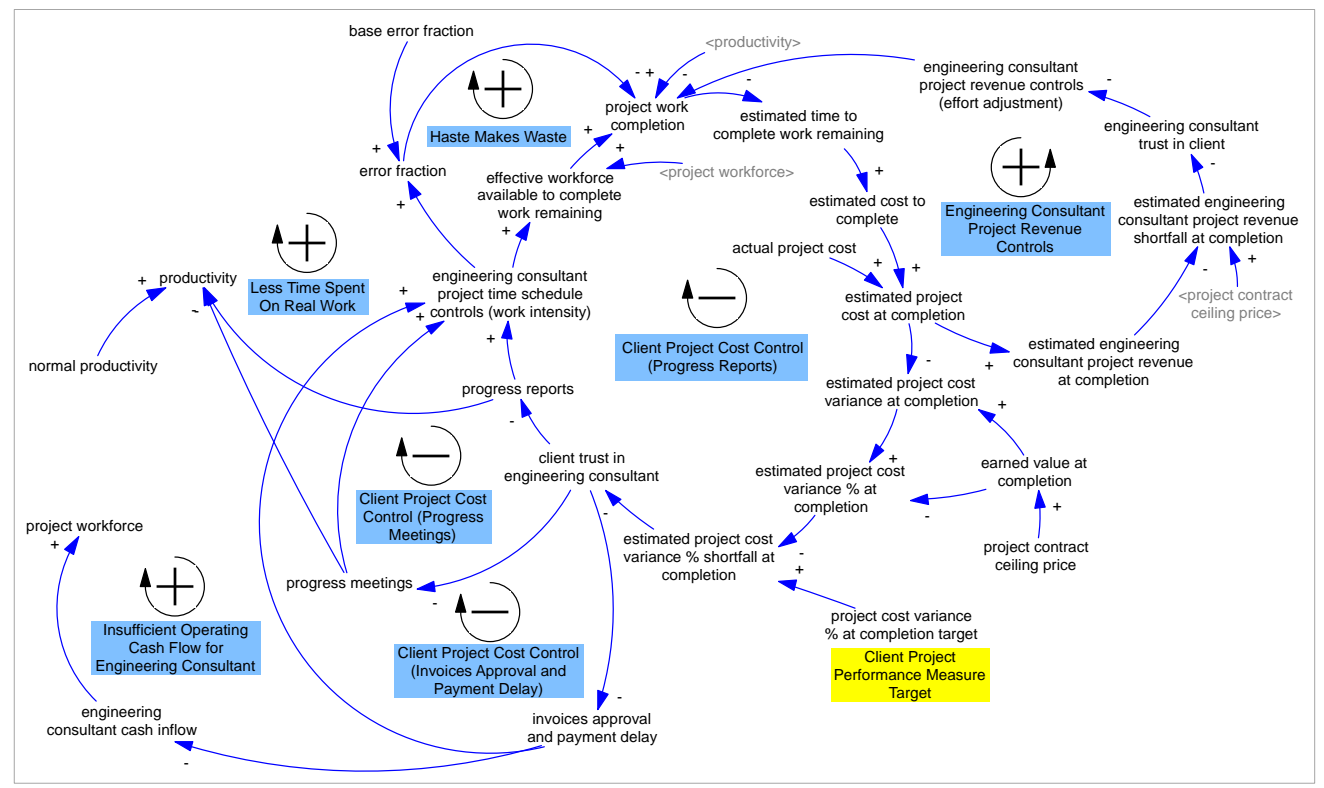

Figure 2: Client project cost controls and their unintended effects (Source: Adapted from this study, Anbari [37], Chitongo and Pretorius [12], and Ford et al. [15]) 
One client project cost control excluded from Figure 2 is 'conducting project progress inspections'; however, its unintended effects are similar to those of progress reports and meetings demands, which are included in Figure 2.

Ford et al. [15] investigated the impact of three engineering consultant / construction contractor project time schedule controls (overtime, work intensity, and adding more people) on project time schedule and cost. They found that the use of work intensity produced the largest amount of rework [15]. In view of their finding, integrating the engineering consultant project time schedule control of work intensity into Figure 2 yields the system dynamics conceptual model shown in Figure 3.

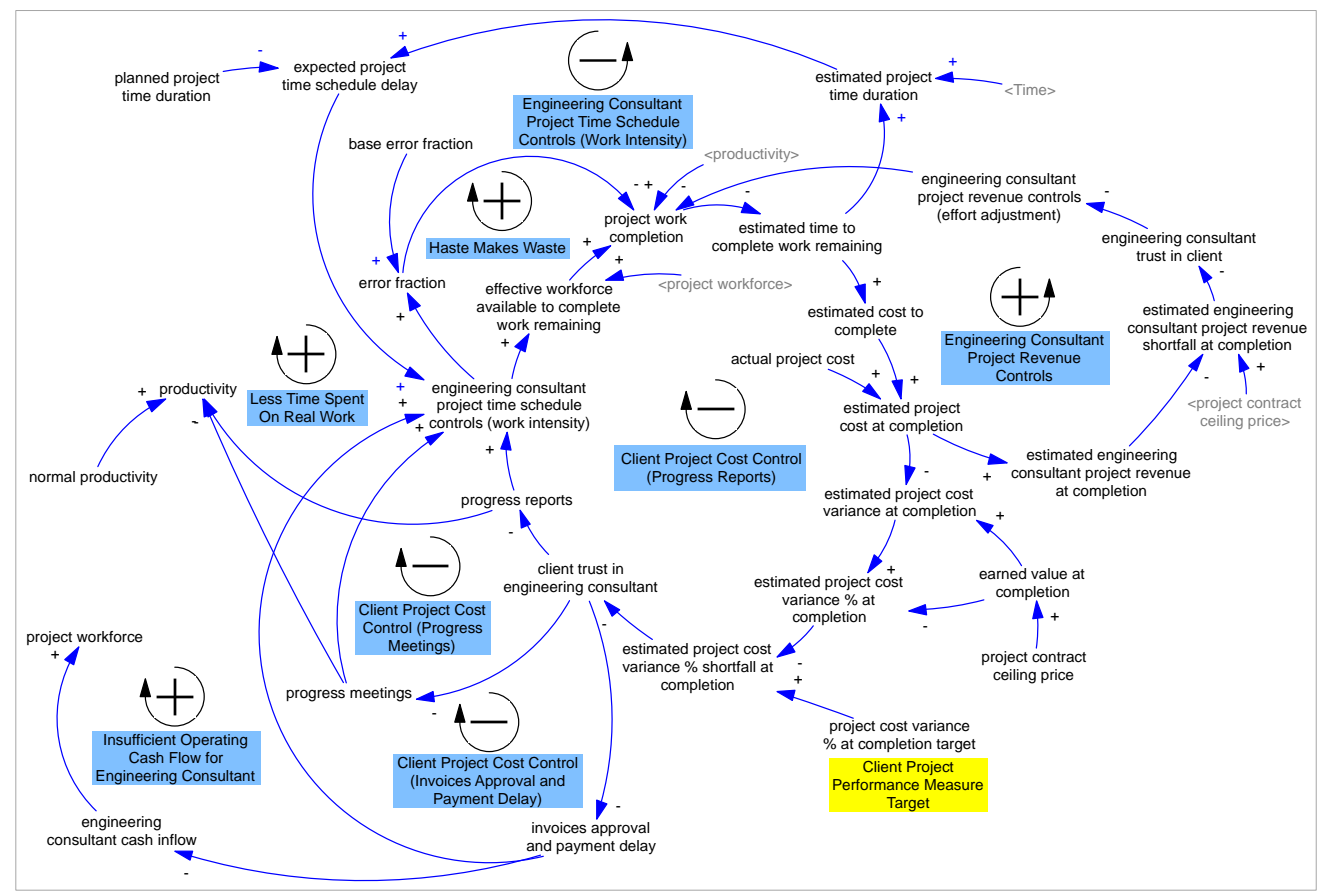

Figure 3: Client project cost controls and their unintended effects (plus engineering consultant project time schedule control - work intensity only) (Source: Adapted from this study, Anbari [37], Chitongo and Pretorius [12], and Ford et al. [15])

The next section presents key results from the second stage of the research study, the initial system dynamics model simulations.

\section{$5 \quad$ INITIAL SYSTEM DYNAMICS SIMULATION MODEL RESULTS}

\subsection{System dynamics simulation model calibration}

An initial system dynamics simulation model of the client project cost controls and their associated unintended effects was formulated, using Vensim DSS software, from the system dynamics conceptual model (Figure 3). This was done by making use of stock and flow diagrams and feedback loops; specifying mathematical equations for the relationships among the variables, ensuring dimensional consistency in all equations; specifying initial conditions; and testing for extreme conditions, as recommended by Martinez-Moyano and Richardson [33] and Sterman [17]. The formal description of the full system dynamics simulation model at stock and flow diagram level will be included as part of a future research publication by the authors of this article.

As part of system dynamics model validation, model calibration entails estimating the values for the model parameters to minimise errors between the model simulation outputs and their associated real-world data [5] [35]. Parvan et al. [5] calibrated their system dynamics simulation model by minimising a pre-defined payoff function formed by a linear combination of three sources of error: the differences between the real-world project data and their model simulations of project time duration, project total cost, and project cost curve. 
This research study adapts the payoff function used by Parvan et al. [5] by incorporating the invoicing curves and the invoice payment curves. Thus key parameters for the initial system dynamics simulation model of client project cost controls and their associated unintended effects, formulated in this study, were calibrated by minimising a payoff function that is a linear combination of four sources of error between the model simulation outputs and their associated real-world project data: project time duration; project cost; project invoicing curve (assumed to be indicative of the project cost curve); and the project invoice payment curve (which is also indicative of the engineering consultant project cash inflow curve).

The key system dynamics simulation model parameters that were calibrated were: engineering consultant-related (base error fraction, normal productivity, workforce adjustment delay, work intensity adjustment delay, and effort adjustment delay); and client project cost control-related (progress reports demand adjustment delay, progress meetings demand adjustment delay, and invoices approval and payment delay adjustment delay).

The actual real-world project used in this study had an initially planned duration of 12 months and an initial cost budget of R13.473 million. The dataset used in the calibration consisted of: actual project time schedule duration (16 months); actual project cost (R16.150 million); actual time-series invoicing data; and actual time-series invoice payment data.

Table 2 summarises the key results of the initial system dynamics simulation model simulations conducted after the calibration, showing the unintended negative effects of client project cost controls on project time schedule and project cost.

Table 2: System dynamics simulation model results after the calibration

\begin{tabular}{|l|l|c|c|c|c|}
\hline \multicolumn{1}{|c|}{$\begin{array}{c}\text { Model simulation } \\
\text { run-name }\end{array}$} & \multicolumn{1}{|c|}{$\begin{array}{c}\text { Description } \\
\text { (client project cost control + } \\
\text { unintended effects) }\end{array}$} & $\begin{array}{c}\text { Project } \\
\text { time } \\
\text { duration } \\
\text { (months) }\end{array}$ & $\begin{array}{c}\text { Project } \\
\text { cost } \\
\text { (R million) }\end{array}$ & $\begin{array}{c}\text { Compared with initial } \\
\text { plan (time schedule } \\
\text { duration of 12 months, } \\
\text { and cost budget of } \text { R13. } \\
\text { 473m) }\end{array}$ \\
\cline { 2 - 6 } & $\begin{array}{c}\text { \% Time } \\
\text { schedule } \\
\text { delay }\end{array}$ & $\begin{array}{c}\text { Cost } \\
\text { over-run }\end{array}$ \\
\hline TC_WI & $\begin{array}{l}\text { None (only engineering consultant } \\
\text { project time control - work intensity) }\end{array}$ & 11.1 & 12.780 & $-8 \%$ & $-5 \%$ \\
\hline TC_WI+UE & $\begin{array}{l}\text { None (only engineering consultant } \\
\text { project time control - work intensity + } \\
\text { unintended effects }\end{array}$ & 11.8 & 13.610 & $-2 \%$ & $1 \%$ \\
\hline TC_WI+UE+CC_M & meetings demand & 11.4 & 13.100 & $-5 \%$ & $-3 \%$ \\
\hline TC_WI+UE+CC_M+UE & meetings demand + unintended effects & 15.7 & 18.070 & $31 \%$ & $34 \%$ \\
\hline TC_WI+UE+CC_R & reports demand & 11.4 & 13.100 & $-5 \%$ & $-3 \%$ \\
\hline TC_WI+UE+CC_R+UE & reports demand + unintended effects & 15.5 & 17.890 & $29 \%$ & $33 \%$ \\
\hline TC_WI+UE+CC_MR & meetings demand + reports demand & 11.2 & 12.920 & $-6 \%$ & $-4 \%$ \\
\hline TC_WI+UE+CC_MR+UE & $\begin{array}{l}\text { meetings demand + reports demand + } \\
\text { unintended effects }\end{array}$ & 19.3 & 22.250 & $61 \%$ & $65 \%$ \\
\hline TC_WI+UE+CC_I & invoice approval and payment delay & 11.4 & 13.140 & $-5 \%$ & $-2 \%$ \\
\hline TC_WI+UE+CC_I+UE & $\begin{array}{l}\text { invoice approval and payment delay + } \\
\text { unintended effects }\end{array}$ & 15.4 & 13.140 & $28 \%$ & $-2 \%$ \\
\hline TC_WI+UE+CC_IMR & $\begin{array}{l}\text { invoice approval and payment delay + } \\
\text { meetings demand + reports demand }\end{array}$ & 11.3 & 13.030 & $-6 \%$ & $-3 \%$ \\
\hline TC_WI+UE+CC_IMR+UE & $\begin{array}{l}\text { invoice approval and payment delay + } \\
\text { meetings demand + reports demand + } \\
\text { unintended effects }\end{array}$ & 16.0 & 16.140 & $34 \%$ & $20 \%$ \\
\hline
\end{tabular}

The simulation results shown in Table 2 indicate that the short-term impact of all the considered client project cost controls looks positive, supporting the intended effect of a reduction in project cost. For instance, increasing the frequency of both progress meetings and reports (simulation TC_WI+UE+CC_MR) resulted in a cost saving of about 4\%. However, when the unintended effects (decrease in productivity, increase in work errors, effort adjustment by the engineering consultant, and insufficient operating cash flow for the engineering consultant, all resulting in a decreased project work completion rate, as shown in Figure 3) of increasing the frequency of both progress 
meetings and reports are considered (simulation run $\mathrm{TC} \_\mathrm{WI}+\mathrm{UE}+\mathrm{CC} \_\mathrm{MR}+\mathrm{UE}$ ), the project cost increases significantly by $65 \%$. Thus the long-term impact of the client project cost controls is counteractive and unintended: instead of the project cost decreasing, it actually goes up substantially. This is an example of a 'better-before-worse' result that is characteristic of dynamic complexity [17].

The negative impact of the client's demand for an increased frequency of project progress reporting from the engineering consultant shown in Table 2 corroborates a similar finding by Rodrigues and Williams [20].

\subsection{Sensitivity analysis}

A multivariate Monte Carlo sensitivity analysis was conducted on the calibrated system dynamics simulation model to test the robustness of the calibration results [17]. This entailed automatically randomly varying the system dynamics simulation model parameters around their calibrated values and re-simulating the model, using Vensim DSS software. The calibrated model parameters that were subjected to sensitivity analysis are: base error fraction; normal productivity; progress reports demand adjustment delay; progress meetings demand adjustment delay; invoices approval and payment delay adjustment delay; and engineering consultant effort adjustment delay. These parameters were specifically chosen because they strongly influence project completion rate, and hence the project time duration and thus project cost (considering a time-based contract).

The results of the sensitivity analysis showed no behaviour mode sensitivity to the simulation results: a 'better-before-worse' result (similar to that shown in Table 2 ) was evident, as shown as an example in Figures 4 and 5 for the use of a combination of progress meetings and reports without and with unintended effects, respectively.

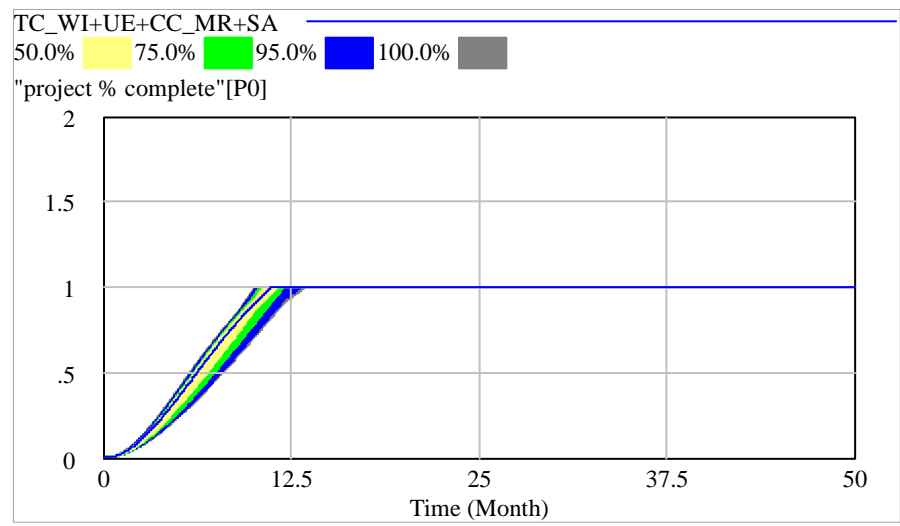

Figure 4: Client project cost controls (progress meetings and reports) without unintended effects (see online version for colour)

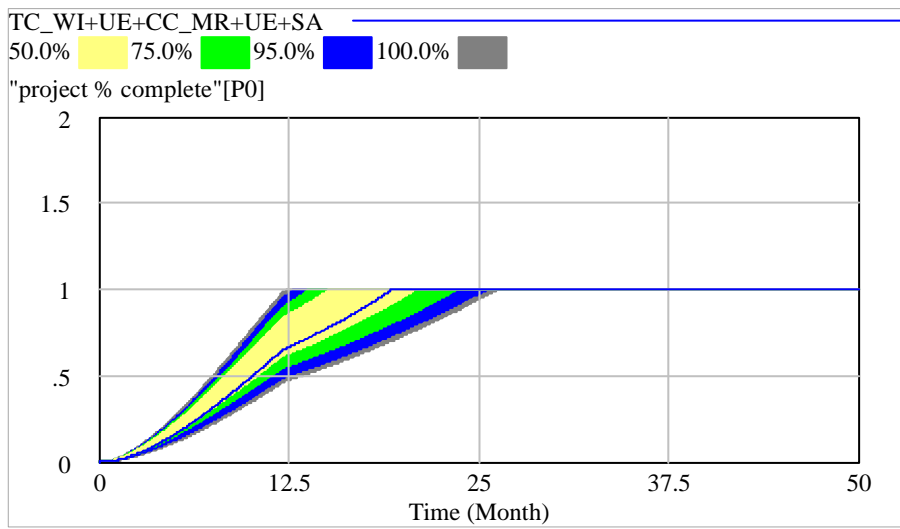

Figure 5: Client project cost controls (progress meetings and reports) with unintended effects (see online version for colour) 
The key objectives of this article were: to investigate, from the existing literature and empirically, some of the client project cost controls and their unintended effects; to formulate an appropriate system dynamics conceptual model; to formulate an appropriate initial system dynamics simulation model; to calibrate the system dynamics simulation model using real-world project data; and to conduct a Monte Carlo sensitivity analysis on some of the key assumptions (model parameters). These objectives were achieved through a two-stage research design.

The first stage was an embedded multiple-case study that resulted in the formulation of a system dynamics conceptual model of client project cost controls and associated unintended effects from a combination of: the existing literature; key findings from an empirical embedded multiple-case study that captured the relevant formal and mental models of the interviewed contemporary client and engineering consultant project managers; and system dynamics' systems thinking tool (causal loop diagram), all in line with the recommendations of Barlas [31], Luna-Reyes and Andersen [32], Martinez-Moyano and Richardson [33], and Sterman [17]. The overall dynamic hypothesis presented in the formulated system dynamics conceptual model is that the client project cost controls (aimed at minimising project cost through increasing pressure / work intensity on the engineering consultant to complete project work faster) generate some counteractive and unintended effect (a decrease in the project work completion rate, and an increase in the project cost) in the case of a time-based contract.

In the second stage of this research study, the system dynamics conceptual model formulated in the previous stage was converted to an initial system dynamics simulation model. Real-world projectspecific data, from a raw-water infrastructure-related project, were then used to calibrate the formulated system dynamics simulation model of the client project cost controls and their unintended effects. Subsequently, the model was simulated: first without any client project cost controls; then with individual client project cost controls (first without and then with the associated unintended effects); and then with a combination of the client project cost controls (also, first without and then with the associated unintended effects).

Initial system dynamics simulation results suggest a 'better-before-worse' result that is characteristic of dynamic complexity [17]. The short-term impact of all the considered client project cost controls supported the intended effect of a reduction in project cost. However, when the unintended effects (decrease in productivity, increase in work errors, effort adjustment by the engineering consultant, and insufficient operating cash flow for the engineering consultant, all resulting in a decreased project work completion rate) are considered, the long-term impact of the client project cost controls is counteractive and unintended: instead of the project cost decreasing, it actually goes up substantially. This was also supported by a multivariate Monte Carlo sensitivity analysis that was conducted to test the robustness of the calibration results.

A future research publication by the authors of this article will, among other objectives, employ more projects in the calibration of the system dynamics simulation model, differentiating between project-specific and non-project specific parameters; and try retrospectively to predict the outcomes of other projects not used in the calibration process, as recommended by Parvan et al. [5]. The future research publication will also include the formal description of the full system dynamics simulation model (part of the initial results of which have been presented in this article) at stock and flow diagram level.

To understand fully the impact of client project controls on project performance, future studies may also formulate an overall system dynamics simulation model that integrates the model presented in this article with other client project performance controls, such as time schedule [12] and quality, and their associated unintended effects.

\section{REFERENCES}

[1] Ansar, A., Flyvbjerg, B., Budzier, A. \& Lunn, D. 2016. Does infrastructure investment lead to economic growth or economic fragility? Evidence from China. Oxford Review of Economic Policy, 32(3), pp. 360-390. 
[2] Vickerman, R. 2018. Can high-speed rail have a transformative effect on the economy? Transport Policy, 62(2018), pp. 31-37.

[3] Toor, S.R. \& Ogunlana, S.O. 2010. Beyond the 'iron triangle': Stakeholder perception of key performance indicators (KPIs) for large-scale public sector development projects. International Journal of Project Management, 28(3), pp. 228-236.

[4] Ngacho, C. \& Das, D. 2014. A performance evaluation framework of development projects: An empirical study of Constituency Development Fund (CDF) construction projects in Kenya. International Journal of Project Management, 32(3), pp. 492-507.

[5] Parvan, K., Rahmandad, H. \& Haghani, A. 2015. Inter-phase feedbacks in construction projects. Journal of Operations Management, 39(2015), pp. 48-62.

[6] Van Wyk, R., Bowen, P. \& Akintoye, A. 2008. Project risk management practice: The case of a South African utility company. International Journal of Project Management, 26(2), pp. 149-163.

[7] De Marco, A. Modeling project behavior: Dynamic tools for early estimates in construction project management. 2006 Project Management Institute Research Conference. Quebec, Canada.

[8] Kaliba, C., Muya, M. \& Mumba, K. 2009. Cost escalation and schedule delays in road construction projects in Zambia. International Journal of Project Management, 27(5), pp. 522-531.

[9] Wen, Q., Qiang, M. \& Peter, G. 2018. Speeding up decision-making in project environment: The effects of decision makers' collaboration network dynamics. International Journal of Project Management, 36(2018), pp. 819-831.

[10] Morris, R.A. 2008. Stop the insanity of failing projects. Industrial Management, 50(6), pp. 20-24.

[11] Standish. 2014. Chaos Report [Online]. Available from: https://www.projectsmart.co.uk/whitepapers/chaos-report.pdf [Accessed 22nd July 2016.

[12] Chitongo, A.M. \& Pretorius, L. 2018. Client project time schedule controls - An empirically-based system dynamics conceptual model. The South African Journal of Industrial Engineering, 29(1), pp. 169-183.

[13] Chitongo, A.M. \& Pretorius, L. Engineering consultant project cash flow controls - an empiricallysupported system dynamics conceptual model. 2017 Proceedings of PICMET '17: Technology management for interconnected world. Portland: PICMET.

[14] Lyneis, J.M. \& Ford, D.N. 2007. System dynamics applied to project management: A survey, assessment, and directions for future research. System Dynamics Review, 23(2-3), pp. 157-189.

[15] Ford, D.N., Lyneis, J.M. \& Taylor, T. Project controls to minimize cost and schedule overruns: A model, research agenda, and initial results. 2007 International System Dynamics Conference, 2007. 1-27.

[16] Sterman, J.D. 1992. System dynamics modeling for project management. Unpublished manuscript. Cambridge, MA: Massachusetts Institute of Technology, pp. 1-12.

[17] Sterman, J.D. 2000. Business dynamics: Systems thinking and modeling for a complex world, $1^{\text {st }}$ ed. Chicago: Irwin/McGraw Hill.

[18] Forrester, J.W. 2007. System dynamics - The next fifty years. System Dynamics Review, 23(2-3), pp. 359370.

[19] Fallahnejad, M.H. 2013. Delay causes in Iran gas pipeline projects. International Journal of Project Management, 31(1), pp. 136-146.

[20] Rodrigues, A.G. \& Williams, T.M. 1998. System dynamics in project management: Assessing the impacts of client behaviour on project performance. Journal of the Operational Research Society, 49(1), pp. 2-15.

[21] Manu, E., Ankrah, N., Chinyio, E. \& Proverbs, D. 2015. Trust influencing factors in main contractor and subcontractor relationships during projects. International Journal of Project Management, 33(7), pp. 14951508.

[22] Odeh, A.M. \& Battaineh, H.T. 2002. Causes of construction delay: Traditional contracts. International Journal of Project Management, 20(1), pp. 67-73.

[23] Sambasivan, M. \& Soon, Y.W. 2007. Causes and effects of delays in Malaysian construction industry. International Journal of Project Management, 25(5), pp. 517-526.

[24] Von Branconi, C. \& Loch, C.H. 2004. Contracting for major projects: Eight business levers for top management. International Journal of Project Management, 22(2), pp. 119-130.

[25] Nasirzadeh, F. \& Nojedehi, P. 2013. Dynamic modeling of labor productivity in construction projects. International Journal of Project Management, 31(6), pp. 903-911.

[26] Chitongo, A.M. \& Pretorius, L. 2017. Engineering consultant project revenue controls: A system dynamics conceptual model. 5th Annual System Dynamics Conference in South Africa, Johannesburg.

[27] Cooper, D.R. \& Schindler, P.S. 2014. Business research methods, $12^{\text {th }}$ ed. New York: MacGraw-Hill/Irwin.

[28] Yin, R.K. 2014. Case study research: Design and methods, $5^{\text {th }}$ ed. California: SAGE Publications, Inc.

[29] Miles, M.B., Huberman, A.M. \& Saldana, J. 2014. Qualitative data analysis: A methods sourcebook, $3^{\text {rd }}$ ed. California: SAGE Publications, Inc.

[30] Atlas.Ti. 2016. ATLAS.ti manuals and documents [Online]. Available from: http://atlasti.com/manualsdocs/ [Accessed 04 April 2016 2016].

[31] Barlas, Y. 1996. Formal aspects of model validity and validation in system dynamics. System Dynamics Review, 12(3), pp. 183-210.

[32] Luna-Reyes, L.F. \& Andersen, D.L. 2003. Collecting and analyzing qualitative data for system dynamics: Methods and models. System Dynamics Review, 19(4), pp. 271-296.

[33] Martinez-Moyano, I.J. \& Richardson, G.P. 2013. Best practices in system dynamics modeling. System Dynamics Review, 29(2), pp. 102-123. 
[34] Mikulskiene, B. \& Pitrenaite-Zileniene, B. 2013. From stakeholders' competition to the balance of interests: System dynamics model of participatory policy. International Journal of Technology, Policy and Management, 13(3), pp. 294-312.

[35] Oliva, R. 2003. Model calibration as a testing strategy for system dynamics models. European Journal of Operational Research, 151(3), pp. 552-568.

[36] Turner, J.R. 2004. Farsighted project contract management: Incomplete in its entirety. Construction Management and Economics, 22(1), pp. 75-83.

[37] Anbari, F.T. 2003. Earned value project management method and extensions. Project Management Journal, 34(4), pp. 12-23. 